\title{
Van laboratoriumbank tot siekbed: Genetiese bevindings in skisofrenie
}

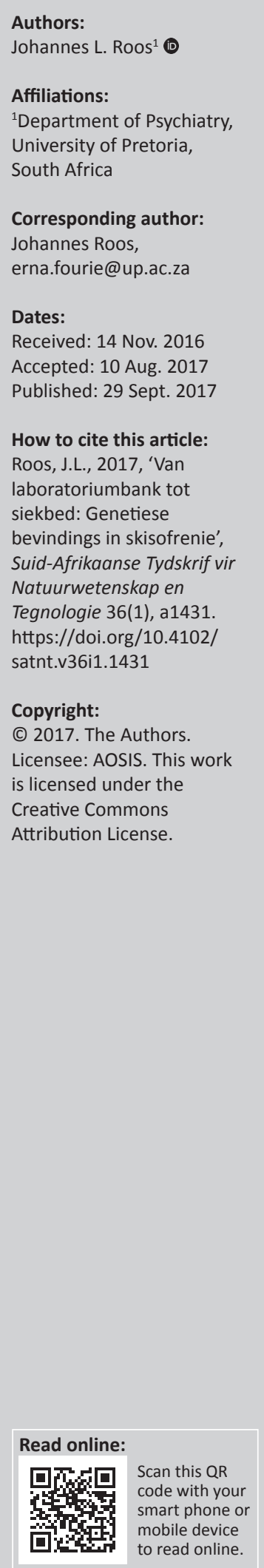

Die komplekse genetiese argitektuur van skisofrenie word kortliks omskryf deur na twee kontrasterende (maar konseptueel verbandhoudende) hipoteses te verwys. Bevindings van die lokus van genoomwye assosiasiestudies (GWAS) en die majorhistoversoenbaarheidskompleks (MHK) op chromosoom 6 en skisofrenie word aangehaal. Klassieke aanvullingskaskade verbonde hieraan word betrek in die eliminering, of 'snoei van sinapse' as deel van die patogenese van skisofrenie. Daar word nader aan die siekbed van skisofreniepasiënte beweeg deur te kyk na die volgende navorsingsbevindings in pasiënte met skisofrenie in die Afrikanerbevolking:

- mikro-uitwissing by die 22q11.2 chromosoom as 'n spesifieke tipe skisofrenie;

- fenotipiese kenmerke van skisofreniepasiënte wat spontane geenmutasies dra;

- skisofrenie wat verwant is aan die vaderlike ouderdom (VOVS) en sosiale funksionering vroeg en later in die lewe van die pasiënte;

- verhoogde selfdoodrisiko in skisofreniepasiënte met koppeling aan chromosoom 13q en hoe mortaliteit in die pasiënte verlaag kan word.

From laboratory to the bedside: Genetic findings in schizophrenia. The complex genetic architecture of schizophrenia is briefly described with reference to two contrasting (but conceptually related) hypotheses. There is reference to genome-wide association studies (GWAS) and the major histocompatibility complex (MHC) locus on chromosome 6 and schizophrenia. Recent findings regarding structural alleles in the classical complement cascade, related to the MHC and implicated in the elimination and 'pruning of synapses', form part of the pathogenesis of schizophrenia. Moving closer to the bedside of schizophrenia patients, the following research findings in the Afrikaner population are discussed:

- micro deletion at 22q11.2 chromosome as a specific subtype of schizophrenia;

- phenotypical characteristics of schizophrenia patients with spontaneous gene mutations;

- paternal age-related schizophrenia (PARS) and social functioning early and later in the lives of these patients;

- increased risk of suicide in schizophrenia patients with linkage to chromosome $13 q$ and how mortality rates can be decreased in these patients.

\section{Genetika van skisofrenie}

Die genetiese argitektuur van skisofrenie is bewys kompleks te wees. Die debat oor die kompleksiteit fokus op die relatiewe belang van twee kontrasterende (maar konseptueel verbandhoudende) hipoteses: die algemene siekte- of algemene alleelmodel (ASAA) en die algemene siekte- of unieke alleelmodel (ASUA).

Die ASAA-model stel voor dat die genetiese risiko in ' $n$ individu en bevolking veroorsaak word deur te veel hoëfrekwensie-variante, wat elk 'n magtige vlak van risiko bydra (McClellan \& King 2010; Risch \& Merikangas 1996).

In kontras stel die ASUA-model voor dat die genetiese risiko in ' $n$ individu verklaar word deur skaars mutasies wat 'n beduidende bydrae lewer. Gevolglik kan die algemene siekte dalk dui op 'n groot aantal (honderde of duisende) verskillende oorsake, met 'n lae frekwensie (tipies minder as $1 / 1000$ individue), maar wat bydra tot 'n groot deel van die bydraende risiko van die gemiddelde.

Die skaars kopie-nommervariante (KNV'e) wat 'n bydrae lewer met 'n hoër risiko om siekte te veroorsaak in die genoom is óf spontaan óf word oorgedra aan nasate. KNV'e is skaars, maar 
wanneer hulle patogenies is (voorkom in 'n funksionele deel van 'n geen), is die risiko hoog dat hulle siekte veroorsaak. Verskeie is al geïdentifiseer, soos 'n baie groot KNV op chromosoom 22q11 en een op chromosoom 7q36.3. Die meeste KNV'e geassosieer met skisofrenie is geïdentifiseer in grootskaalse studies van onverwante pasiënte en is nie voorheen bewys ' $n$ veroorsakende faktor in families te wees nie. Hulle neig om spontane mutasies te wees, eerder as om in families voor te kom (Xu et al. 2011).

Daar is navorsers wat voorstel dat die waargenome teenstrydigheid tussen 'algemene' en 'unieke' allele nie net vals is nie, maar ook nie bruikbaar is om vordering te maak om die genetiese basis van psigiatriese toestande beter te verstaan nie (Visscher, Brown, McCarthy \& Yang 2012).

Dit is die kombinasie van alleelfrekwensie, effekgrootte en funksionele kenmerke wat die sukses sal bepaal van nuwe eksperimentele paradigmas soos algehele eksoom of genoom-genoomreeksbepaling. Empiriese resultate stel voor dat byna die helfte van die genetiese variasie gekenmerk word deur enkelnukleotied-polimorfisme (ENP) op kommersiële genoomwye merkers, maar dat individuele veroorsakende merkers ' $n$ geringe effek het. Hulle kom tot die gevolgtrekking dat groter eksperimentele steekproewe noodsaaklik is vir ons om die onderliggende biologie van psigiatriese toestande te verstaan.

'n Artikel deur die Skisofrenie-werkgroep van die Psigiatriegenoomkonsortium is in Nature 2014 gepubliseer, en breedvoerig in die media bespreek. Daar is onder meer geskryf dat die bevindings van hierdie studie die potensiaal inhou om nuwe insigte oor die oorsake van skisofrenie te bring. Pasiënte en familie wou weet hoe hierdie bevindings hulle siekte raak.

Hierdie groot molekulêre genetiese studie van skisofrenie bewys die krag van GWAS (Genoom-wye Assosiasiestudie) om 'n groot aantal loci te identifiseer wat risiko inhou. (Schizophrenia Working Group of the Psychiatric Genomics Consortium 2014). Die studiegroep rapporteer'n genoomwye assosiasiestudie met skisofreniepasiënte. Die studie het 36989 gevallestudies en 113075 kontrolestudies ingesluit. Hulle identifiseer 128 onafhanklike assosiasies wat oor 108 loci strek, en wat genoomwyd beduidend is. Altesame 83 van die loci is nie voorheen beskryf nie. Assosiasies is verryk met gene wat uitdrukking vind in die brein, en wat biologiese moontlikhede vir die bevindings bied. Baie bevindings het die potensiaal om nuwe insig in die etiologie van skisofrenie te gee. Assosiasies by DRD2 en verskeie gene, betrokke by glutamenergiese neurotransmissie, beklemtoon molekules wat bekend en moontlik van potensiële belang kan wees in skisofrenie en wat sou inpas by bekende patofisiologiese hipoteses van die siekte (Schizophrenia Working Group of the Psychiatric Genomics Consortium 2014).

Onafhanklik van gene wat uitdrukking in die brein vind, is daar assosiasies wat verryk is in gene in weefsel wat 'n belangrike rol in immuniteit speel. Dit sou ondersteuning bied aan die spekulatiewe verbintenis tussen die immuniteitstelsel en skisofrenie. Die navorsers kom tot die gevolgtrekking dat variasie in die geïdentifiseerde gene 'n impak het op funksie om die risiko vir skisofrenie te verhoog, maar al die vrae kan nie deur genetika beantwoord word nie. Die oorvleueling dui sterk daarop dat algemene en unieke variantstudies aanvullend eerder as antagonisties is. Navorsers beklemtoon dat meganistiese studies, gedryf deur unieke genetiese variasie, baie inligting oor skisofrenie kan verskaf (Schizophrenia Working Group of the Psychiatric Genomics Consortium 2014).

\section{Major- \\ histoversoenbaarheidskompleks- lokus op chromosoom 6 en skisofrenie}

Met die aanvang van genoomwye assosiasiestudies (GWAS) het dit moontlik geword om groot bevolkings van aangetaste individue (gevalle) en kontrolegroepe te skandeer. Daar word gebruik gemaak van hoëdigtheid-genotipering van enkel-nukleotiedpolimorfismes (ENP's). In die proses word algemeen voorkomende allele wat geassosieer word met algemene siekte, identifiseer. Nadat dit bekend geword het dat enorme getalle individue benodig word om die relatiewe klein effekgrootte van algemeen voorkomende allele op te spoor, is groot pogings tot samewerking in psigiatriese siekte van stapel gestuur. In skisofrenie het hierdie ondersoek gelei tot die identifisering van meer as 100 loci wat bydra tot skisofrenie. Dié bevindings was 'n uitstaande mylpaal in hierdie navorsingsveld (Ripke et al. 2014). Die hoop is uitgespreek dat elk van die 100 loci geïdentifiseer, ons sal lei tot die onderliggende geen of variant wat die siekteassosiasie dryf. Wanneer die stukkies van die legkaart aanmekaar gesit word, sal die patofisiologiese meganisme van skisofrenie blootgelê word.

'n Onlangse studie gepubliseer in Nature deur Sekar et al. (2016) neem die eerste kritiese stap, deur funksionele allele te identifiseer wat die mees beduidende GWASlokus onderlê. Hierdie lokus lê binne die majorhistoversoenbaarheidskompleks- (MHK) lokus op chromosoom 6.

Die MHK-lokus is bekend vir sy rol in immuniteit. Dit bevat 18 hoogs polimorfe menslike leukosietantigeen- (MLA) gene. Hulle enkodeer 'n groot groep van antigeenmolekules. In sommige outo-immuniteitsiektes is daar genetiese assosiasies met die MHK-lokus. Allele is geïdentifiseer van HLA-gene. Skisofrenie se assosiasie met die MHK kon tot voor hierdie bevindings nie verklaar word nie.

Versigtige ondersoek van die skisofrenie-GWAS-lokus in die MHK toon aan dat strukturele allele van die komplement 4(K4) lokus skisofrenie se risiko verhoog. Hierdie strukturele allele verhoog komplement 4A- (K4A) RNA-vlakke in die menslike brein, met ' $n$ gevolglike verhoging in komplement 3 (K3), met meer snoei van sinapse. 'n Muis-uitklopmodel van komplement 4 (K4) toon aan dat sinaptiese snoei in die 
visuele sisteem in die brein onderbreek word. Hierdie bevindings in die diermodel stem ooreen met die model waar toename in menslike komplement 4A- (K4A) uitdrukking lei tot toename in sinaptiese snoei in skisofrenie. Ander invloede wat die risiko vir hierdie komplekse toestand verhoog, moet ook in ag geneem word. Dit sluit omgewings en ander genetiese invloede in. Komplement 4 (K4) is 'n kritiese komponent van die klassieke komplementkaskade. Dit is ' $n$ ingeboude immuniteitstelsel-baan wat patogene en sellulêre debris vinnig herken en elimineer. Ander gene in die klassieke komplementkaskade word betrek in die eliminasie of 'snoei' van sinapse (Sekar et al. 2016).

In mense vind uitgebreide eliminasie van sinapse in adolessensie en vroeë volwassenheid plaas, en wel in assosiasiegebiede van die serebrale korteks. Hierdie deel van die serebrale korteks het baie uitgebrei in onlangse menslike evolusie en in skisofrenie blyk dit aangetas te wees.

Sinaptiese eliminasie in die menslike assosiasiekorteks duur voort van adolessensie tot die derde dekade van lewe. Hierdie laat fase van kortikale rypwording, wat mense onderskei van ander primate, stem ooreen met die periode waarin skisofrenie klinies geïdentifiseer word en kognitiewe funksie afneem.

Die vernaamste patologiese bevindings in die brein van pasiënte met skisofrenie sluit in die verlies van kortikale grysstof sonder seldood. Die pasiënte toon abnormale kortikale verdunning en 'n verlaagde aantal sinaptiese strukture by kortikale piramidale neurone.

In die brein word komplementreseptore verteenwoordig deur mikroglia, die fagositiese immuniteitselle van die sentraal senuwee stelsel (SSS). Die moontlikheid dat neuronmikroglia-interaksie via die komplementkaskade bydra tot die patogenese van skisofrenie, sou ' $n$ verklaring bied vir die langdurige kliniese observasie oor die ouderdom van aanvang en verlies van sinapse in die brein van skisofreniepasiënte. Skisofrenie ontstaan of vererger weens oormatige of ontoepaslike sinaptiese snoei deur mikroglia gedurende vroeë adolessensie en vroeë volwassenheid (Sekar et al. 2016).

\section{Wat kom na die algemene siekte- of algemene alleel en algemene siekte- of unieke alleel-model?}

As ons aanbeweeg van die ASAA en die algemene siekte- of unieke alleel, is dit nou duidelik dat die vatbaarheid vir siekte waarskynlik die gevolg is van die interaksie van verskeie genetiese veranderinge. 'n Duidelike aantoonbare subgroep van genetiese veranderinge hou verband met NMDAR- (N-Metiel-D-Asparaatreseptor) funksie en die interaksie daarvan met dopamien. Algemene variasie met lae penetrasie, tesame met omgewingsfaktore kan genoegsaam wees om skisofrenie te sneller in sommige pasiënte. Unieke, hoëpenetrasie-variante sal bydra tot patologie in sommige pasiënte, wat moontlik kan lei tot 'n ernstige vorm van siekte met vroeë aanvang (Ahn et al. 2014). Kortliks opgesom, kan 'n mens veronderstel dat die hoë oorerflikheid van skisofrenie veroorsaak word deur allele wat op individuele vlak nie nodig of noodsaaklik is om die siekte te veroorsaak nie (Friston et al. 2016).

Baie ander genetiese bevindings in skisofrenie betrek gene wat sinaptiese proteïene enkodeer. Diverse sinaptiese abnormaliteitekan'ninteraksiehêmetdiekomplementsisteem en ander bane wat lei tot oormatige stimulasie van mikroglia en eliminasie van sinapse gedurende adolessensie en vroeë volwassenheid (Sekar et al. 2016).

Met die voorafgaande bespreking kan die vraag gestel word hoe die bevindings van hulp kan wees in die kliniese situasie langs die siekbed? Hoewel dit van min tot geen belang in die kliniese situasie sal wees nie, kan ons redeneer dat beter insigte in die patofisiologie van psigiatriese toestande kan bydra tot die destigmatisering van die toestande en beklemtoon dat hier 'n duidelike biologiese inslag is.

In die verdere diskoers sal ek nader wil beweeg aan die siekbed deur die volgende aspekte van skisofrenie te oorweeg:

- Mikro-uitwissing by 22q11.2-chromosoom as 'n spesifieke tipe skisofrenie;

- Fenotipiese kenmerke van skisofreniepasiënte wat spontane geenmutasies dra;

- Vaderlike ouderdomsverwante skisofrenie;

- Verhoogde selfdoodrisiko in skisofreniepasiënte met koppeling aan chromosoom 13q.

\section{Mikro-uitwissing by 22q11.2 en skisofrenie}

Mikro-uitwissing by die 22q11.2-lokus is 'n spontane KNV beskryf in skisofrenie (Karayiorgou et al. 1995). Sedert hierdie bevindings is daar ' $n$ sterk en spesifieke tweerigtingverband vasgestel tussen die teenwoordigheid van 22q11.2-mikrouitwissing en psigose. Tot ' $n$ derde van alle laat-adolessente of vroeë volwassenes wat mikro-uitwissing het, ontwikkel skisofrenie of skiso-affektiewe steuring (SAS) (Gothelf et al. 2007).

Die 22q11-uitwissingsindroom kom gewoonlik voor as 'n sporadiese mutasie, maar oorerwing speel ' $n$ rol in $10 \%$ van gevalle. Die 22q11.2-uitwissingsindroom het 'n hoogs veelsoortige fenotipiese uitdrukking. Dit sluit in gesigdismorfologie, kardiovaskulêre anomalie, orale kliefgespletenheid, timus, paratiroïed en leerabnormaliteite. Die uitwissing kom voor in tot $85 \%$ van individue wat die fenotipe van die velo-kardio-gesigsindroom het (Scambler 2000).

Die mikro-uitwissing word opgespoor deur die fluoressensiehibrasietegniek wat in situ (FISH) gedoen word (Scambler 2000). Die voorkoms van hierdie uitwissing word geskat op 1 
uit 5950 lewende geboortes (Botto et al. 2003). Dit maak die 22q11.2-mikro-uitwissingsindroom die tweede mees algemene genetiese sindroom, waar Down Sindroom die mees algemene sindroom is.

In ons genetiese navorsing in Afrikaner-skisofreniepasiënte is die frekwensie van die mikro-uitwissing by $22 \mathrm{q} 11$ bepaal. Ons studie bevestig die voorheen gerapporteerde $2 \%$ frekwensie van die mikro-uitwissing in volwasse skisofreniepasiënte. Ons het ook 'n tweestadiumsiftingsprotokol voorgestel om hierdie pasiënte te identifiseer (Wiehahn et al. 2004).

Volgens Bassett en Chow (1999) het pasiënte met twee of meer van die volgende siftingskriteria ' $n$ verhoogde risiko vir die 22q11-uitwissingsindroom:

- hipernasale spraak, geskiedenis van spraakterapie, velofaringiale inkompetensie, gesplete verhemelte (gewoonlik submukosaal)

- kenmerkende gesigsvoorkoms: byvoorbeeld lang smal gesig, nou oogsplete, plat wange, prominente neus, klein ore, klein mond, teruggetrekte ken

- leerprobleme, geskiedenis van spesiale onderwys, intellektuele inkorting (grenslyn tot matig)

- kongenitale hartdefekte byvoorbeeld ventrikulêre septumdefek, tetralogie van Fallot, regskantige aortaboog, dubbele aortaboog

- ander beduidende kongenitale abnormaliteite byvoorbeeld klompvoete, polidaktilie, nierabnormaliteite, kifose of skoliose, hipospadie

- geskiedenis van hipokalsemie en/of hipoparatiroïdisme

- geskiedenis van atemie of erge immuuntekort in kinderjare.

Ons toon aan dat die siftingsprosedure vir die kliniese kenmerke wat ooreenstem met die 22q11.2uitwissingsindroom relatief eenvoudig is om uit te voer. Ons was in staat om pasiënte met die sindroom akkuraat te identifiseer. Een derde van die pasiënte wat twee of meer van die Bassett \& Chow se kriteria het, het positief getoets in die FISH-toets, en daar was geen vals negatiewe nie. Deur hierdie prosedure uit te voer, verminder dit die getal pasiënte wat 'n relatief duur FISH-toets benodig (Wiehahn et al. 2004).

In 'n ideale omgewing sal die behandeling van skisofrenie fokus op die voorkoming van psigose. By kwesbare individue met die 22q11.2-uitwissingsindroom sou die voorkomende behandeling moontlik wees. Nuwe ontwikkelinge in die neurobeelding van babas en kinders het die potensiaal om die kritieke periodes van breinontwikkeling beter te verstaan (Ross 2010). Volgens Gothelf et al. 2004, sou vroeë herkenning van 22q11-uitwissingsindroom-pasiënte, wat'n hoë risiko vir psigose het, vroeë ingryping moontlik maak. Hierdie ingreep sou die langtermynprognose by sulke pasiënte verbeter. Dit is ook bekend dat indien pasiënte 'n genetiese diagnose vir hulle toestand kry, hulle minder skuldgevoelens en ontoepaslike blaam oor die gedragsmanifestasies van hulle toestand sal beleef (Bassett \& Chow 1999).
Tydens genetiese raadgewing van pasiënte met die 22q11uitwissingsindroom is dit belangrik om te besef dat daar ' $n$ $50 \%$ kans is vir die oordra van die uitwissing met elke swangerskap. Die probleem is egter dat die omvang van die fenotipe nie voorspel kan word nie (Bassett \& Chow 1999). Hierdie individue het $25 \%$ kans om 'n psigose te ontwikkel. Sulke pasiënte behoort gereeld opgevolg te word om vroeë gedragsabnormaliteite en prodromale simptome te evalueer. Dié aspekte van die siekte moet dan toepaslik gehanteer word.

Die opsporing van 22q11-uitwissingsindroom verander die genetiese raadgewing en sorg van hierdie pasiënte, in vergelyking met ander pasiënte met skisofrenie wat die uitwissing nie het nie. Die opsporing van 'n kopienommervariant in skisofrenie kan soos in Alzheimer-demensie lei tot klassifikasie volgens major veroorsakende genetiese faktore. As ons dit vergelyk met Alzheimer- demensie, geassosieer met die geenmutasie genaamd beta-amiloied-voorloperproteïn (APP) kan skisofrenie, verwant aan die 22q11.2 uitwissing, 'n subtipe met spesifieke behandelingsgevolge word (Bassett, Scherer \& Brzustowicz 2010).

Ons het ook die kliniese beeld van Afrikanerpasiënte met 22q11.2-uitwissingsindroom nagegaan. Die kliniese beeld waarmee hierdie pasiënte presenteer, varieer baie. Byna al die pasiënte het 'n vroeë aanvang van siekte gehad met 'n swak prognose. Hulle funksionering was laag en hulle moes in 'n hoogs gestruktureerde omgewing versorg word. Vroeë gedragsafwykings en inkorting van die werkende geheue was prominente simptome in al die pasiënte. Daar was ook ander psigopatologie, insluitend patologiese lagsindroom, 'n familiegeskiedenis van kraniostenose, asook een pasiënt wat 'n laat aanvang van psigose gehad het (Lombard \& Roos 2011).

Kliniese waaksaamheid vir twee of meer van Bassett se kriteria en bevestiging deur 'n FISH-analise van die 22q11.2uitwissingsindroom, is noodsaaklik. Toepaslike kliniese hantering is belangrik, want hierdie tipe skisofrenie het 'n swakker prognose en toepaslike genetiese raadgewing is ook belangrik (Lombard \& Roos 2011).

\section{Fenotipiese kenmerke van skisofreniepasiënte wat spontane geenmutasies dra}

Skisofrenie dra in die algemeen by tot funksionele inkorting wêreldwyd en is hoogs oorerflik en geneties heterogeen (Rodriguez-Murillo, Gogos \& Karayiorgou 2012). Vooruitgang in genomika het bygedra tot die volgende generasie van studies oor die genetika van skisofrenie. Unieke gene wat kopienommervariante ontwrig (KNV'e), enkel-nukleotiedvariante (ENV) en klein insluitings en weglatings dra duidelik by tot die siekte (Gulsuner et al. 2013; McClellan \& King 2010; Stefansson 2008; Walsh et al. 2008; Xu et al. 2008, 2011, 2012). Hulle dra'n hoë patogenisiteitwaarde in hul spontane vorm.

'n Spontane mutasie is ' $n$ genetiese verstelling wat die eerste maal voorkom in een familielid weens ' $n$ mutasie in die 
kiemsel (ovum of sperm) van een ouer of in die embrio self. Gene wat ontwrig is in skisofrenie en skiso-affektiewe steurnis kan blootgelê word deur spontane mutasies in aangetaste persone van andersins gesonde families (sporadiese gevalle).

Ons het voorheen 'n genoomwye skandering gedoen vir spontane KNV'e en ENV'e in 'n goed omskrewe groep van trio's van Afrikanerfamilies in Suid-Afrika. Dit het bestaan uit individue met skisofrenie en hulle biologiese ouers (Xu et al. 2008).

Genoomwye skanderings toon 'n beduidende rol vir spontane KNV'e en ENV'e in die genetiese argitektuur van skisofrenie. In 'n studie in 2015 is skisofrenie ontleed, gebaseer op die teenwoordigheid van spontane mutasies en poog ons om die verhouding tussen die genotiep en fenotiep verder te ondersoek (Malherbe et al. 2015). Ons ondersoek die veranderlikes van fenotipes in drie breë kategorieë: funksionering voor aanvang van siekte, kliniese voordoening, die verloop van die siekte en die funksionele uitkoms. Individue met skisofrenie wat óf spontane KNV'e, spontane ENV'e óf geen mutasies het nie, is met mekaar vergelyk deur die parameters in ag te neem. Werkvaardighede is die ergste aangetas in pasiënte met spontane KNV'e. Meer leerabnormaliteite het voorgekom in pasiënte met spontane ENV'e. Pasiënte met een of van die ander mutasies het ouer ouers by geboorte gehad en erger funksioneringuitkomste soos gemeet deur die Spesifieke Vlak van Funksionering (SVVF). Ons vind geen verband tussen behandelingsweerstandigheid en die teenwoordigheid van spontane mutasies nie. Die gekombineerde oorweging van funksionele uitkoms en vroeë gedragsafwykings het 'n hoër voorspellingwaarde vir onderliggende genetiese vatbaarheid gehad. Weens die unieke aard van spontane mutasies is die getal pasiënte wat ondersoek is, klein.

Waardevolle fenotipiese kenmerke is geïdentifiseer by skisofreniepasiënte met spontane mutasies, en groter groepe pasiënte behoort bestudeer te word. 'n Groter vlak van disfunksie word geassosieer met die teenwoordigheid van spontane KNV'e. Dit is nie verbasend nie, aangesien KNV'e 'n groot aantal gene beïnvloed wat sal lei tot groter funksionele inkorting.

Vroeë gedragsafwykings kom voor in 'n subgroep van pasiënte. Leerabnormaliteite, as een van die sewe areas waarin afwykings voorkom, is beduidend ingekort in pasiënte met spontane ENV'e. Hierdie bevinding stem ooreen met die literatuur wat daarop dui dat skisofrenie 'n neuro-ontwikkelingsteurnis is met wortels in die kinderdae.

Hierdie bevindings kan van hulp wees wanneer daar besluit moet word of 'n spontane mutasie in 'n pasiënt met skisofrenie moontlik teenwoordig kan wees. Onnodige duur genetiese ondersoeke kan gevolglik tot ' $n$ minimum beperk word.

\section{Vaderlike ouderdomsverwante skisofrenie (VOVS) en sosiale funksionering vroeg en later in lewe}

'n Verhoogde risiko vir 'n kind om skisofrenie te ontwikkel is teenwoordig indien die vader se ouderdom by konsepsie al reeds gevorderd is. Onafhanklik van moederlike ouderdom, het die kinders van ouer vaders meer vatbaarheid vir 'n verskeidenheid van toestande (Goriely \& Wilkie 2012). Studies toon ' $\mathrm{n}$ verhoogde risiko vir skisofrenie wanneer die vader al 'n gevorderde ouderdom bereik het (Malaspina et al. 2001), sowel as 'n hele reeks van ander psigiatriese morbiditeite, soos outistiese spektrumsteurnis, (Grether et al. 2009) (Hultman et al. 2011); bipolêre steurnis (Frans et al. 2008); epilepsie (Vestergaad, Mork, Madsen \& Olsen 2005); obsessief-kompulsiewe steurnis (Wu et al. 2012) en 'n verlaging in kognitiewe vermoëns in die babajare en kinderjare (Saha et al. 2009).

Daar is nie ooreenstemming oor hoe om ' $\mathrm{n}$ gevorderde vaderlike ouderdom te definieer nie. Sommige outeurs is meer spesifiek in dié verband, terwyl ander redeneer dat daar nie 'n duidelike afsnypunt is nie. Vaderlike ouderdomsverwante skisofrenie (VOVS) is operasioneel gedefinieer deur Rosenfield et al. (2010) as persone sonder 'n familiegeskiedenis van skisofrenie of psigose, en waar die vader se ouderdom by geboorte ouer as 35 jaar was.

Die literatuur dui daarop dat daar wat baie steurnisse betref, nie' $n$ duidelike afsnypunt is waar vaderlike ouderdom beskou word as 'gevorderd' nie. Dit lyk eerder of daar 'n liniêre verhoogde risiko vir 'n steurnis is met verhoogde vaderlike ouderdom. Miller et al. (2010) stel 'n J-vormige kurwe voor vir die verhouding tussen vaderlike ouderdom en die risiko vir skisofrenie. In 'n meta-analise van vaderlike ouderdom en ' $n$ risiko vir skisofrenie waarin manlike kinders met vroulike kinders vergelyk is, is bevind dat daar ' $n$ beduidende toename in risiko is vir skisofrenie in afstammelinge met verhoogde vaderlike ouderdom ( $\geq 30$ jaar ouderdom). Daar is ook ' $n$ beduidende toename in die risiko vir die siekte gevind in die afstammelinge van jonger vaders $(\leq 25$ jaar), wat geassosieer word met 'n verhoogde risiko vir mans, maar nie vroue nie. Die risikopersentasie in die bevolkings is $10 \%$ vir vaderlike ouderdom $>30$ jaar en $5 \%$ vir vaderlike ouderdom $\leq 25$ jaar in alle studies (Miller et al. 2010).

Onlangse genomiese studies dui daarop dat die ouderdom van die vader by konsepsie 'n belangrike faktor is om te bepaal wat die aantal spontane mutasies in hulle afstammelinge sal wees (Kong et al. 2012). Akkumulerende mutasies en chromosomale abnormaliteite in reproduktiewe kiemselle kan miskien 'n verklaring bied vir die grootste deel van die risiko vir psigiatriese steurnisse geassosieer met gevorderde vaderlike ouderdom (Goriely et al. 2003). Nuwe mutasies kan moontlik'n verklaring bied waarom skisofrenie bly voortbestaan in die bevolking ondanks ' $n$ beduidende reproduktiewe agterstand van aangetaste persone (Malaspina et al. 2001). 
Die effek van vaderlike ouderdom kan dalk ook die risiko verhoog deur epigenetiese meganismes, geassosieer met die omgewing tydens ontwikkeling, beide intra-uterien en postnataal. Gratten et al. 2016 gebruik modelle van bevolkingsgenetika gebaseer op empiriese observasies van sleutelparameters om die genetiese verband tussen vaderlike ouderdom en risiko vir psigiatriese toestande te ondersoek. Hierdie parameters sluit in mutasietempo, voorkoms en oorerflikheid. Dié modelle stel voor dat ouderdomverwante mutasies 'n onwaarskynlike verklaring vir die meeste van die verhoogde risiko van psigiatriese steurnis in kinders van ouer vaders kan wees. Hierdie navorsers stel 'n model voor waar 'n swak korrelasie tussen ouderdom by geboorte van die eerste kind en vatbaarheid vir psigiatriese toestande bestaan wanneer epidemiologiese observasies in ag geneem word. Die resultate dui op genetiese risikofaktore wat gedeel word deur ouer vaders en hulle kinders as 'n meer aanvaarbare verduideliking, in plaas van spontane mutasies vir die risiko van kinders van ouer vaders. Op die basis van beskikbare empiriese data stel hulle 'n model voor waar ouderdomverwante mutasie nie meer as sowat $10 \%-20 \%$ van die verhoogde risiko verklaar nie.

Pasiënte met skisofrenie en hulle naaste familie het ingekorte sosiale funksionering, gevolglik kan dit oorweeg word dat ingekorte sosiale funksionering ' $n$ intermediêre fenotipe van die siekte kan wees. Navorsingsresultate wat verband hou met sosiale funksionering in die algemene bevolking en gevorderde vaderlike ouderdom, stel voor dat die risiko tussen gevorderderde vaderlike ouderdom en skisofrenie minstens gedeeltelik'n nadelige effek van sosiale funksionering insluit (Liebenberg et al. 2016; Weiser et al. 2008).

Skisofrenie word beskou as 'n siekte wat beïnvloed word deur verskeie gene en omgewingsfaktore. Hierdie faktore kan ook bydra tot die manifestasies van ander psigiatriese toestande of intermediêre fenotipes soos ingekorte kognitiewe of sosiale funksionering. Die nadelige effek van die risikofaktore manifesteer as psigiatriese steurnis (skisofrenie) wanneer individue 'n sekere ernstigheidsdrempel oorskry (Weiser et al. 2008). Gevolglik hoef gevorderderde vaderlike ouderdom nie noodwendig 'n risikofaktor vir 'n spesifieke psigiatriese steurnis soos skisofrenie te wees nie. Dit kan egter die risiko vir breinwanfunksionering wees wat moontlik by uitsondering die drempel vir 'n kliniese diagnose oorskry.

Die navorsingsvraag wat ons gestel het, is of gevorderde vaderlike ouderdom by geboorte korreleer met vroeë gedragsabnormaliteite in die eerste tien jaar van lewe (wat sosiale funksionering insluit) en ook met die SVVF in volwassenheid in sporadiese gevalle met skisofrenie en skiso-affektiewe steurnis in 'n stigtersbevolking. Na 'n model van logistiese regressie toegepas is, is daar ' $n$ beduidende negatiewe verband gevind tussen vaderlike ouderdom by geboorte en sosiale disfunksie as vroeë gedragsabnormaliteit. Verdere regressie-analise dui op 'n beduidende negatiewe verhouding tussen vaderlike ouderdom by geboorte en die interpersoonlike verhoudings later in die pasiënte se lewe. Vroeë sosiale disfunksie kan 'n fenotipiese kenmerk van
VOVS verteenwoordig. Verdere navorsing word geverg om die verband tussen vroeë sosiale disfunksie en inkorting in interpersoonlike verhoudings later in die lewe te verduidelik (Liebenberg et al. 2016).

\section{Verhoogde risiko vir selfdood in skisofreniepasiënte met koppeling aan chromosoom 13q}

Die identifisering van koppeling aan chromosoom 13 kan inligting gee oor die identifisering van hoë selfdoodrisiko vir pasiënte vroeg in die verloop van hulle siekte. Dit kan sorg dat ' $n$ omvattende behandelingsplan in plek gestel word om morbiditeit en mortaliteit in skisofreniepasiënte te voorkom.

Koppelinganalise is 'n standaardprosedure om die plek van gene te identifiseer wat genetiese siekte veroorsaak (Cui et al. 2010). Die hoofvoordeel van hierdie benadering is om gene wat 'n matige tot ingrypende effek het op te spoor (Risch \& Merikangas 1996). Koppelingstudies wat gedoen is van skisofrenie toon positiewe bevindings in baie verskillende dele van die genoom. 'n Verwarrende kombinasie van herhaling en nieherhaling van resultate is gevind. Daar is ' $n$ duidelike heterogenisiteit met geen duidelike herhaling in enige gebied nie. Geen gebied word geïmpliseer in meer as $20 \%$ van onafhanklike studies nie (Sullivan 2005). Hierdie variërende studie-uitkomste kan dalk afhang van die lokus en fenotipiese heterogenisiteit, onvoldoende steekproefgrootte, verskille in vasstelling, merkerstelle, voorouers en statistiese metodologie (Ng et al. 2009).

Voorheen het ons skisofrenie gekoppel aan chromosoom 13q. In 'n opvolgstudie het ons die genomiese dekking verhoog om die koppelinggebiede beter te definieer. Daar is 'n 2-cM genoomwye koppelingskandering gedoen op 'n uitgebreide groep van Afrikanerfamilies. Die 13q 32-34-lokus het na vore gekom as die duidelikste koppelingslokus in hierdie bevolking. Fyn kartering van die 13q 32-34-lokus toon aan dat die MYO16 (Myosin XVI) geen bydrae tot die genetiese vatbaarheid vir skisofrenie lewer nie. Uitdrukkinganalise van die MYO16-geen in breinmonsters van pasiënte en kontrolegroepe identifiseer ' $n$ beduidend verhoogde vlak van uitdrukking in pasiënte met skisofrenie. Die MYO16geen is ' $n$ lid van die neuronale tirosien-fosforileerde adaptor (verwerker) vir die P13K- (NYAP) familie van fosfoproteïen. As daar ingemeng word met die groep van fosfoproteïen in muise, beïnvloed dit die ontwikkeling van breingrootte en neurietverlenging. Dit toon ook 'n interaksie met NRXN1, 'n sinaptiese neuronale bindingsmolekule wat presinaptiese en postsinaptiese neurone aanmekaar heg, en speel ' $n$ belangrike rol in kognitiewe prosesse.

'n Beter insig in die genetiese basis van skisofrenie kan lei tot vroeë opsporing en behandeling van die siekte. Skisofrenie het ' $n$ sterk genetiese komponent en dis bekend dat dit in families voorkom. Ons koppel skisofrenie in families van die geneties geïsoleerde Afrikanerbevolking van Suid-Afrika aan chromosoom 13q $(n=51), 1 p(n=23)$ en die kombinasie 
van $13 q \& 1 p(n=18)$. Daar is gebruik gemaak van nieparametriese en parametriese koppelinganalise. Ons beskryf die kliniese fenotipe en funksionering oor 'n opvolgtydperk in pasiënte gegroepeer volgens die spesifieke genetiese loci. Ons navorsing toon aan dat pasiënte met 'n koppeling aan die 13q-chromosoom 'n 4.3 keer groter kans het om met skiso-affektiewe steurnis (SAS) gediagnoseer te word in vergelyking met koppeling aan chromosoom 1 . Van die 20 pasiënte wat diagnoseer is met SAS het elf aan skisoaffektiewe steurnis, bipolêre tipe, gely en 9 aan SAS, depressiewe tipe (Roos et al. 2016).

Byna die helfte van die pasiënte met SAS het 'n geskiedenis van selfdoodpogings in vergelyking met $24.1 \%$ van pasiënte gediagnoseer met skisofrenie. Meer voltooide selfdood het voorgekom in pasiënte met koppeling aan 13q as met koppeling aan 1p (Roos et al. 2016). SAS bied 'n voortdurende uitdaging aan psigiatrie se klassifikasiesisteem. Daar is onsekerheid oor die grense van hierdie toestand met betrekking tot skisofrenie en affektiewe steurnis (Jager et al. 2011). Psigiatriese fenotipes word tans gedefinieer volgens beskrywende kriteria (American Psychiatric Association [DSM 5] 2013). Die bruikbaarheid van beskrywende kriteria in biologies genetiese navorsing word bevraagteken. Die Navorsingsdiagnostiese Kriteria (NDK) (Spitzer, Endicott \& Robins 1978) onderskei beter tussen hierdie steurnisse, gebaseer op die gemoedspatroon en psigotiese simptomatologie as die DSM-sisteem. Die NDK se definisie fokus op die temporale samevoeging van die major affektiewe sindroom met spesifieke tipes psigotiese kenmerke. In die DSM 5 is die SAS hersien as 'n longitudinale en nie 'n eenmalige ('cross-sectional') diagnose nie (American Psychiatric Association [DSM 5] 2013). Volgens DSM 5 (American Psychiatric Association [DSM 5] 2013) kan SAS slegs gediagnoseer word as die kerngemoedsepisode vir die duur van die siekte teenwoordig is.

Dit is in kontras met skisofrenie met gemoedsimptome. SAS kom ewe veel voor as skisofrenie en is epidemiologies relevant. Genetiese epidemiologie ondersteun 'n sterk genetiese komponent vir SAS, met soortgelyke oorerflikheid as skisofrenie en die spektrum van bipolêre gemoedstoornis. Die genetiese variante wat die vatbaarheid vir SAS beïnvloed, is makliker om te identifiseer as in die geval van bipolêre steurnis of skisofrenie op sigself.

Met SAS-pasiënte is daar 'n hoër voorkoms van selfdood as by skisofreniepasiënte (Radomsky et al. 1999). Potkin et al. 2003 identifiseer soortgelyke risikofaktore vir selfdoodgedrag in skisofrenie en SAS-pasiënte. Die risikofaktore, geïdentifiseer in hierdie studie, stem ooreen met ons bevindings en sluit in faktore soos vorige selfdoodpogings, middel- en alkoholmisbruik, die rook van sigarette, selfdoodgeneigdheid, depressie en angs. Klosapien verminder die relatiewe risiko vir selfdoodgedrag, insluitend die aantal selfdoodpogings en hospitalisasies om selfdood te verhoed in SAS- en skisofreniepasiënte met $24 \%$, in vergelyking met olansapien (Meltzer et al. 2003). Hierdie risikofaktore kan moontlik bruikbaar wees vir klinici om risikofaktore te evalueer vir selfdoodgedrag in
SAS- en skisofreniepasiënte. Die koppeling aan chromosoom $13 q$, soos bevind in ons studie, kan dalk 'n addisionele risiko faktor word vir selfdoodgedrag in SAS-pasiënte, indien hierdie bevindings in verdere studies herhaal word. Koppelinganalise kan dié pasiënte vroeg in die verloop van die siekte identifiseer en verseker dat 'n omvattende benadering toegepas word om morbiditeit en mortaliteit te voorkom. Tegnologiese vooruitgang in koppelinganalise kan moontlik die identifikasie van die pasiënte bespoedig.

\section{Slot}

Baie vordering is gemaak in navorsing oor die genetika van skisofrenie. Verskillende groeperings voer aan die ontdekkings verklaar slegs 'n klein gedeelte van die genetiese risiko vir skisofrenie en vertel ons nog min van die aard van skisofrenie. Daar is ook klinici wat afvra hoe die bevindings ons help wanneer dit kom by die bedkant van die pasiënt met skisofrenie.

In hierdie oorsig het ek probeer wys hoe genetiese bevindings in skisofrenie van Afrikanerpasiënte gebruik kan word by die bedkant van pasiënte.

22q11.2 mikro-uitwissing word beskryf as 'n spesifieke tipe skisofrenie. 'n Siftingprosedure om hierdie pasiënte vroegtydig op te spoor en toepaslik te hanteer word bespreek. Dit word beklemtoon dat hierdie tipe skisofrenie 'n swakker prognose het en dat toepaslike genetiese raadgewing belangrik is.

Fenotipiese kenmerke in pasiënte met spontane mutasies, soos leerabnormaliteite vroeg in hulle lewe, asook groter funksionele inkorting later in lewe, word uitgelig om hierdie pasiënte te identifiseer.

Vaderlike ouderdomsverwante skisofrenie (VOVS) word bespreek. Fenotipiese kenmerke van hierdie toestand word geïdentifiseer om vroeë opsporing te vergemaklik.

Verhoogde risiko vir selfdood in skisofreniepasiënte met koppeling aan chromosoom 13q, kan hierdie pasiënte moontlik vroeër identifiseer en mortaliteit in hierdie pasiënte op die lang termyn verminder.

\section{Erkenning}

Prof. M. Karayiorgou, Columbia Universiteit, New York, vir die samewerkingsooreenkoms en die Nasionale Navorsingstigting (NNS) se jaarlikse aansporingsbeurs sedert 2010; aan outeur Elsabé Brits vir noukeuringe en stylvolle taalversorging. Erna Fourie vir tegniese versorging van manuskrip. Die outer ontvang 'n NNS-aansporingsbeurs sedert 2010 met 'n gradering van die NS.

\section{Mededingende belange}

Die outeur verklaar dat hy geen finansiële of persoonlike verbintenis met enige party wat hom nadelig of voordelig kon beïnvloed het in die skryf van hierdie artikel nie. 


\section{Literatuurverwysings}

Ahn, K., Gotay, N., Andersen, T.M., Anvari, A.A., Gochman, P., Lee, Y. et al., 2014, 'High rate of disease-related copy number variations in childhood onset schizophrenia', Molecular Psychiatry 19, 568-572. https://doi.org/10.1038/mp.2013.59

American Psychiatric Association (DSM 5), Diagnostic and statistical manual of mental disorders, 5th ed. American Psychiatric Publishing Arlington, WA 2013

Bassett, A. \& Chow, E.W., 1999, '22q11 deletion syndrome: A genetic subtype of schizophrenia', Biological Psychiatry 46(7), 882-891. https://doi.org/10.1016/ S0006-3223(99)00114-6

Bassett, A.S., Scherer, S.W. \& Brzustowicz, L.M., 2010, 'Copy number variations in schizophrenia: Critical review and new perspectives on concepts of genetics and disease', American Journal of Psychiatry 167, 899-914. https://doi.org/10.1176/ appi.ajp.2009.09071016

Botto, L.D., May, K., Fernhoff, P.M., Correa, A., Coleman, K., Rasmussen, S.A. et al., 2003, 'A population-based study of the 22q11.2 deletion: Phenotype, incidence, and contribution to major defects in the population', Pediatrics 112, 101-107. https://doi.org/10.1542/peds.112.1.101

Cui, Y., Li, G., Li, S. \& Wu, R., 2010, 'Designs for linkage analysis and association studies of complex diseases', Statistical Methods in Molecular Biology 260, 219-242. https://doi.org/10.1007/978-1-60761-580-4

Frans, E.M., Sandin, S., Reichenberg, A., Lichtenstein, P., Lângström, N. \& Hultman C.M., 2008, 'Advancing paternal age and bipolar disorder', Archives of General Psychiatry 65, 1034-1040. https://doi.org/10.1001/archpsyc.65.9.1034

Friston, K., Brown, H.R., Siemerkus, J. \& Stephan, K.E., 2016, 'The dysconnection hypotheses (2016)', 176(2-3), 83-94. https://doi.org/10.1016/j.schres.2016. 07.014

Goriely, A., McGrath, J., Hultman, C.M., Wilkie, A. \& Malaspina, D., 2013, '\#“Selfish spermatogonial selection": A novel mechanism for the association between advanced paternal age and neurodevelopmental disorders', American Journal of Psychiatry 170, 599-608. https://doi.org/10.1176/appi.ajp.2013.12101352

Goriely, A. \& Wilkie, A.D.M., 2012, ‘Paternal age effect mutations and selfish spermatogonial selection: Causes and consequences for human disease', The American Journal of Human Genetics 90, 125-200. https://doi.org/10.1016/j. ajhg.2011.12.017

Gothelf, D., Fernstein, C., Thompson, T., Gu, E., Penniman, L. \& Van Stone, E., 2007 'Risk factors for the emergence of psychotic disorders in adolescents with 22q11.2 deletion syndrome', American Journal of Psychiatry 164, 663-669. https://doi. org/10.1176/ajp.2007.164.4.663

Gothelf, D., Presburger, G., Zohar, A.H., Burg, M., Nahmani, A., Frydman, M., Shohat M., Inbar, D., Aviram-Goldring, A., Yeshaya, J., Steinberg, T., Finkelstein, Y., Frisch, A., Weizman, A. \& Apter, A., 2004 'Obsessive-compulsive disorder in patients with A., Weizman, A. \& Apter, A., 2004 'Obsessive-compulsive disorder in patients with
velocardiofacial (22q11 deletion) syndrome', American Journal of Medical velocardiofacial (22q11 deletion) syndrome', American
Genetics Part B: Neuropsychiatric Genetics $126 \mathrm{~B}(1), 99-105$.

Gratten, J., Wray, N.R., Peyrot, W.J., McGrath, J.J., Visscher, P.M. \& Goddard, M.E., 2016 , 'Risk of psychiatric illness from advanced paternal age is not predominantly
from de novo mutations', Nature Genetics 48, 718-724. https://doi.org/10.1038/ ng.3577

Grether, J.K., Anderson, M.C., Croen, L.A., Smith, D. \& Windham, G.C., 2009, 'Risk of autism and increasing maternal and paternal age in a large North American Population', American Journal of Epidemiology 170, 1118-1126. https://doi. Population', American
org/10.1093/aje/kwp247

Gulsuner, S., Walsh, T., Watts, A.C., Lee, M.K., Thorton, A.M., Casadei, S. et al., 2013 'Spatial and temporal mapping of de novo mutations in schizophrenia to a fetal prefrontal cortical network', Cell 154,518-529. https://doi.org/10.1016/j. prefrontal cortical
cell.2013.06.049

Hultman, C.M., Sandin, S., Levine, S.Z., Lichtenstein, P. \& Reichenberg, A., 2011, 'Advancing paternal age and risk of autism: New evidence from a populationbased study and a meta-analysis of epidemiological studies', Molecular Psychiatry 16(2), 1203-1212. https://doi.org/10.1038/mp.2010.121

Jager, M., Haacks, S., Beckev, T. \& Frasch, K., 2011, 'Schizoaffective disorder - an ongoing challenge for psychiatric nosology', European Psychiatry 36(3), 159-165. https://doi.org/10.1016/j.eurpsy.2010.03.010

Karayiorgou, M., Morris, M.A., Morrow, B., Sprintzin, R.J., Goldberg, R., Borrow J. et al., 1995, 'Schizophrenia susceptibility associated with interstitial deletions of chromosome 22q11', Proceedings of the National Academy of Sciences of the United States of America 92, 7612-7616. https://doi.org/10.1073/pnas.92. 17.7612

Kong, A., Frigge, M.L., Masson, G., Besenbacher, S., Sulem, P., Magnusson, G. et al., 2012 , 'Rate of de novo mutations and the importance of father's age to disease risk', Nature 488, 471-475. https://doi.org/10.1038/nature11396

Liebenberg, R., Van Heerden, B., Ehlers, R., Du Plessis, A.M.E. \& Roos, J.L., 2016 'Advancing paternal age at birth is associated with poorer social functioning earlier and later in life of schizophrenia patients in a founder population, Psychiatry Research 243, 185-190. https://doi.org/10.1016/j.psychres.2016. 06.045

Lombard, M. \& Roos, J.L., 2011, 'Velocardiofacial syndrome - a syndrome with many faces', SAJP 17(3), 82-88. https://doi.org/10.4102/sajpsychiatry.v17i3.305

Malaspina, D., Harlap, S., Fennig, S., Helman, D., Nahon, D., Feldman, D. \& Susser, E.S., 2001, 'Advancing paternal age and the risk of schizophrenia', Archives of General Psychiatry 58, 361-367. https://doi.org/10.1001/archpsyc.58.4.361

Malherbe, P.J., Roos, J.L., (Jr.), Ehlers, R., Karayiorgou, M. \& Roos, J.L., 2015 'Phenotypic features of patients with schizophrenia carrying de novo gene mutations: A pilot study', Psychiatry Research 225, 108-114. https://doi. org/10.1016/j.psychres.2014.10.024
McClellan, J. \& King, M.C., 2010, 'Genetic heterogeneity in human disease', Cell 141 210-217. https://doi.org/10.1016/j.cell.2010.03.032

Meltzer, H.Y., Alphs, L., Green, A.I., Altamura, A.C., Anand, R., Bertoldi, A. et al., 2003, 'Clozapine treatment for suicidalilty in schizophrenia: International Suicide Prevention Trial (InterSePT)', Archives of General Psychiatry 60(1), 82-91. https:// doi.org/10.1001/archpsyc.60.1.82

Miller, B., Messias, E., Miettunen, J., Alaräisänen, A., Järvelin, M.R., Koponen, H. et al., 2010, 'Meta-analysis of paternal age and schizophrenia risk in male versus female offspring', Schizophrenia Bulletin 37, 1039-1047. https://doi.org/10.1093/schbul/ sbq011

Ng, M., Levinson, D.F., Faraone, S., Suarez, B., DeLisi, L., Ariname, T. et al., 2009, 'Metaanalysis of 32 genome-wide linkiage studies of schizophrenia', Molecular Psychiatry 14(8), 774-785. https://doi.org/10.1038/mp.2008.135

Potkin S. G., Alphs, L., Hsu, C., Krisnan, R., Anand, R., Young, F.K., Meltzer, H., Green, A., ImterSePT Study Group, 2003, 'Redicting suicidal risk in schizophenic and schizoaffective patients in a prospective two-year trial', Biol Psychiatry 54(4), 444-452.

Radomsky, E.D., Haas, G.L., Mann, J.J. \& Sweeney, J.A., 1999, 'Suicidal behaviour in patients with schizophrenia and other psychotic disorders', American Journal of Psychiatry 156, 1590-1595. https://doi.org/10.1176/ajp.156.10.1590

Ripke, S., Neale, B.M., Corvin, A., Walters, J.T., Farh, K.H., Holmans, P.A. et al., 2014 'Biological insights from 108 Schizophrenia Associated Genetic Loci', Nature 511, 421-427. https://doi.org/10.1038/nature13595

Risch, N. \& Merikangas, K., 1996, 'The future of genetic studies of complex human diseases', Science, New Series 273(5281), L1516-L1517.

Rodriguez-Murillo, L., Gogos, J.A. \& Karayiorgou, M., 2012, 'The genetic architecture of schizophrenia: New mutations and emerging paradigms', Annual Review of Medicine 63, 63-80. https://doi.org/10.1146/annurev-med-072010-091100

Roos, J.L., Malherbe, P.M., Ehlers, R. \& Karayiorgou, M., 2016, 'Phenotyic characterization of schizophrenia patients with linkage to chromosoom 13q, $1 p$ \& combine $13 q=1 p^{\prime}$, poster 5th SIRS Congress, Florence, Italy, 2-6th April.

Rosenfield, P.J., Kleinhaus, K., Opter, M., Perrin, M., Learned, N., Goetz, R. et al., 2010 'Later paternal age and sex differences in schizophrenia symptoms', Schizophrenia Research 116, 191-195. https://doi.org/10.1016/j.schres.2009.10.020

Ross, R.G., 2010, 'Neuroimaging the infant: The application of modern neurobiological methods to the neurodevelopmental hypothesis of schizophrenia', American methods to the neurodevelopmental of Psychiatry 167, 1017-1018. https://doi.org/10.1176/appi.ajp.2010. Journal of

Saha, S., Barnett, A.G., Foldi, C., Burne, T.H., Eyles, D.W., Buka, S.L., McGrath, J.J., 2009, 'Advanced paternal age is associated with impaired neurocognitive outcomes during infancy and childhood', PLoS Med 6, e40.

Scambler, P.J., 2000, 'The 22q11 deletion syndromes', Human Molecular Genetics 9, 2421-2426. https://doi.org/10.1093/hmg/9.16.2421

Schizophrenia Working Group of the Psychiatric Genomics Consortium. 2014 July 24.

Sekar, A., Bialas, A.R., De Rivera, H., Davis, A., Hammond, T.R., Kamitaki, N. et al., 2016, 'Schizophrenia risk from complex variation of complement component 4', Nature 530, 177-183. https://doi.org/10.1038/nature16549

Spitzer, R.L., Endicott, J. \& Robins, E., 1978, 'Research diagnostic criteria: Rational and reliability', Archives of General Psychiatry 35(6), 773. https://doi.org/10.1001/ archpsyc.1978.01770300115013

Stefansson, H., Rujescu, D., Cichon, S., Pietiläinen, O.P.H., Ingason, A., Steinberg, S. et al., 2008, 'Large recurrent microdeletions associated with schizophrenia', Nature 445, 2332-2236. https://doi.org/10.1038/nature07229

Sullivan, P.F., 2005, 'The genetics of schizophrenia', PloS Medicine 2(7), e212. https:// doi.org/10.1371/journal.pmed.0020212

Vestergaard, M., Mork, A., Madsen, K.M., Olsen, J., 2005, 'Paternal age and epilepsy in the offspring', European Journal of Epidemiology 20, 1003-1005.

Visscher, P.M., Brown, M.A., McCarthy, M.I., Yang, J., 2012, 'Five years of GWAS discovery', The American Journal of Human Genetics 90, 7- 24

Walsh, T., McClellan, J.M., McCarthy, S.E., Addington, A.M., Pierce, S.B., Cooper, G.M et al., 2008, 'Rare structural variants disrupt multiple genes in neurodevelopmental pathways in schizophrenia', Science 320, 539-543. https://doi.org/10.1126/ pathways in schizop
science. 1155174

Weiser, M., Reichenberg, A., Werbeloff, N., Kleinhaus, K., Lubin, G., Shmushkevitvh, M., Caspi A., Malaspina, D., Davidson, M., 2008, 'Advanced paternal age at birth is associated with poorer social functioning in adolessent males: Shedding light in a associated with poorer social functioning in adolessent males: Shedding light

Wiehahn, G.J., Bosch, G.P., Du Preez, R.R., Pretorius, H.W., Karayiorgou, M. \& Roos, J.L., 2004, 'Assessment of the frequency of the 22q11 deletion in Afrikaner schizophrenia patients', American Journal of Medical Genetics Part B (Neuropsychiatric Genetics) 129B, 20-22. https://doi.org/10.1002/ajmg.b.20168

Wu, Y., Liu, X., Luo, H., Deng, W., Zhao, G., Wang, Q., Zhang, L., Ma, X., Liu, X., Murray, R.A., Collier, D.A., Li, T., 2012, 'Advanced paternal age increases the risk of schizophrenia and obsessive-compulsive disorder in a Chinese Han population', Psychiatry Res. 198:353-359.

Xu, B., lonita-Laza, I., Roos, J.L., Boone, B., Woodrick, S., Su, Y. et al., 2012, 'De novo gene mutations highlight patterns of genetic and neural complexity in
schizophrenia', Nature Genetics 44, 1365-1369. https://doi.org/10.1038/ng.2446 u, B., Roos, J.L., Dexheimer, P., Boane, B., Plummer, B., Levy, S. et al., 2011, 'Exome sequencing supports a de novo mutational paradigm in schizophrenia', Nature Genetics 43, 864-868. https://doi.org/10.1038/ng.902

Xu, B., Roos, J.L., Levy, S., Van Rensburg, E.J., Gogos, J.A. \& Karayiorgou, M., 2008 'Strong association of de novo copy number mutations with sporadic schizophrenia', Nature Genetics 40, 880-885. https://doi.org/10.1038/ng.162 